Article

\title{
An Effective Framework for Monitoring and Measuring the Progress towards Sustainable Development in the Peri-Urban Areas of the Greater Cairo Region, Egypt
}

\author{
Muhammad Salem ${ }^{1,2, *(\mathbb{D})}$, Naoki Tsurusaki ${ }^{3}$, Prasanna Divigalpitiya ${ }^{3}\left(\mathbb{D}\right.$ and Emad Kenawy ${ }^{2,4}$ \\ 1 Graduate School of Human-Environment Studies, Kyushu University, Fukuoka 819-0395, Japan \\ 2 Faculty of Urban and Regional Planning, Cairo University, Giza 12613, Egypt; E.kenawy@liverpool.ac.uk \\ 3 Faculty of Human-Environment Studies, Kyushu University, Fukuoka 819-0395, Japan; \\ tsurusaki.naoki.127@m.kyushu-u.ac.jp (N.T.); prasanna@arch.kyushu-u.ac.jp (P.D.) \\ 4 Department of Geography and planning, University of Liverpool, L697ZT Liverpool, UK \\ * Correspondence: m.salem@kyudai.jp; Tel.: +81-809-081-1340
}

Received: 10 March 2020; Accepted: 23 April 2020; Published: 27 April 2020

check for updates

\begin{abstract}
Sustainable development (SD) has become a crucial challenge globally, particularly in developing countries and cities. SD of peri-urban areas (PUA) has been tackled by a limited number of studies, unlike that of urban areas or cities. The PUAs of Greater Cairo (GC) are no exception; no study had addressed the state of the PUAs in terms of SD. Thus, this study sought to measure and evaluate the progress towards the SD in the PUAs of Greater Cairo, Egypt. Thirteen indicators were extracted from selected documents of the competent international organizations to measure and evaluate the performance of SD in the study area. The study resulted in a variety of charts and maps to explain the progress of SD in each municipality of the PUAs and then classify these municipalities based on their performance in sustainability indicators. The results revealed a wide gap between PUAs' municipalities and the urban core of Greater Cairo. These results can help urban planners and decision-makers to better recognize the underdeveloped areas on the Greater Cairo peripheries, and hence, to develop the appropriate strategies and policies to improve SD in such areas.
\end{abstract}

Keywords: measurement; evaluation; sustainable development; sustainable development indicator; peri-urban area; Greater Cairo; Egypt

\section{Introduction}

Sustainable development (SD) has become an urgent topic in contemporary development issues [1]. $\mathrm{SD}$ is the organizing principle to meet human development goals [2-5] and aims to improve the quality of life in both urban and rural areas [6,7]. SD has received extensive care and support from the developed countries since the Brundtland report in 1987, then it was been adopted by developing countries after the Earth Summit in Rio in 1992 [8,9]. Since then, SD has been at the forefront of international and national agendas [4].

Measuring and evaluating the progress of SD is a crucial step towards its implementation $[4,10,11]$. Evaluation of SD is a comprehensive process to measure the improvement of the indicators of the social, economic, and environmental dimensions for a specific area and then compare them with the international and national targets [12-14]. This process is significant in the context of the development planning and supporting decision-making procedures at different spatial levels towards achieving Sustainable Development Goals (SDGs) [1]. There is a wide diversity of approaches and tools used to measure and evaluate SD. However, indicators have become the most commonly accepted approach to 
assess SD, at various levels [7,15]. Hence, international organizations have developed sets of indicators for the measurement and evaluation of SD. For instance, the United Nations General Assembly prepared a preliminary set of 232 indicators to measure progress toward reaching SDGs [16-18].

Sustainable development indicators (SDIs) are effective tools that allow policymakers and planners to measure the socioeconomic and environmental impacts within a specific territory [14]. These indicators simplify measuring the progress towards achieving SD [19] and should be valid on a broad geographical scale [20]. SDIs aim to evaluate and benchmark SD conditions and trends across time and space and monitor progress toward SDGs and their targets [21].

It is widely accepted that SDI should cover the three dimensions of SD; social, economic, and environmental [20]. Nevertheless, these dimensions have been examined partially by a group of researchers such as Shaaban, who only investigated the social and environmental aspects during his study in Egypt [22], or Diaz-Chavez, [23] whose study in Mexico focused on economic and environmental dimensions, disregarding social features. Panda et al. have only examined features associated with social sustainability within the Indian cities [24].

A rich body of literature and studies has addressed measuring SD in the urban area [6,14,25-30]. For instance, Tanguay et al [14] developed an approach for the selection of sustainable development indicators (SDI) on an urban level, based on 188 indicators retrieved from 17 relevant studies. Nagy et al [4] have selected 39 indicators to gauge the SD in Cluj metropolitan area in Romania. Pires et al [25] have localized 20 indicators to be appropriate to measure the SD in a set of cities and municipalities in Portugal. Zulaica has chosen 19 indicators to evaluate the SD of Mar del Plata city in Argentina [20]. However, the measurement of SD outside urban areas has been addressed in only a few studies, particularly rarely in the case of peri-urban areas between urban and rural territories $[4,7,23,31,32]$.

A peri-urban area (PUA) is a transitional zone between urban and rural areas [33-35] where urban and rural characteristics are mixed [36-40]. In some countries, other terms, like rural-urban fringe, rurban, and exurban, have been used when referring to PUA contexts [33,41]. A PUA is found at the edge of a functional urban region, and its boundary changes rapidly as the urban area expands and restructures. Figure 1 shows the peri-urban area location within a metropolitan region.

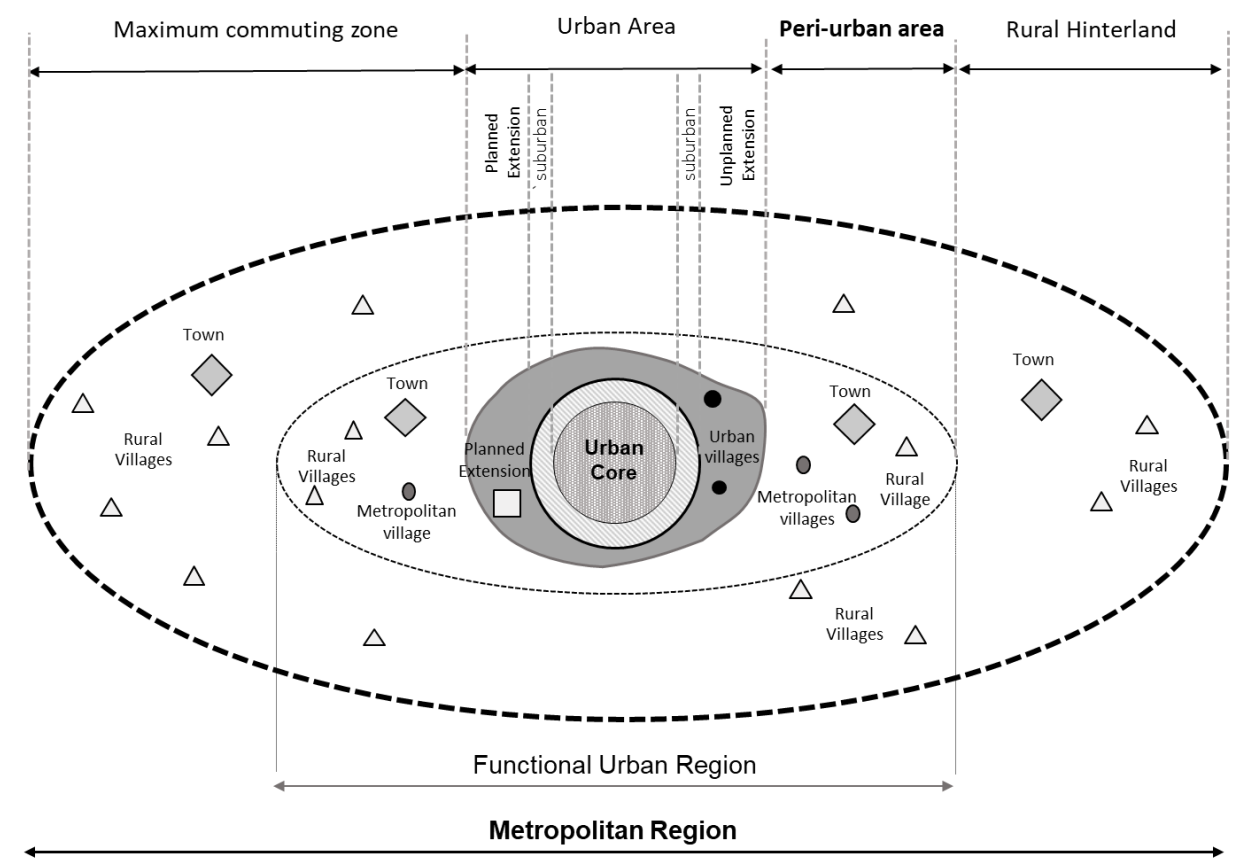

Figure 1. Peri-urban area (PUA) location within the metropolitan region. Source: the authors based on Bryant et al, 1982 and Piorr et al., 2011. 
PUAs constitute the homes of various groups of people, including lower-income classes who are vulnerable to the negative impacts of both urban and rural systems. These include lack of access to basic services, facilities, and infrastructure, and bad conditions of the built environment [23]. Environmental changes also affect these areas and their citizens by rapid loss of agricultural land. Nevertheless, PUAs suffer from a lack of plans and studies, which has led to informal and haphazard development, which in turn ultimately threatens the sustainability of the resources in these territories $[38,41]$.

This paper seeks to fill the gap in previous studies by developing a framework for monitoring and evaluating the progress of SD at PUA level, and then applying it to the PUAs of the Greater Cairo region in Egypt. PUAs of the Greater Cairo region (GCR) cover one third of the total territory area and a quarter of its population [42-44]. Despite the spatial and functional importance of PUAs in the Greater Cairo region, no study has addressed the state of PUAs in terms of SD [23,45-47]. Therefore, the added value of this study mainly lies in the development of a framework to monitor and measure the progress of the SD in the PUAs of GCR. In addition to evaluation of PUA municipalities against the proposed framework, the study combines quantitative data analysis with GIS approaches and techniques to produce various maps of municipalities' classifications, based on the outcomes of this monitoring and measuring of the SD levels.

This study is structured around three main sections after this introduction. Section 2, Material and Methods, discusses the theoretical background of the indicators framework and explains how this framework may lead to better monitoring and evaluation of SD and its trends. Section 3, Results and Discussion, applies this framework with reference to PUAs of GCR, discusses the outcomes of this application, and ultimately discusses the shortcomings of these results in comparison with previous findings and a few suggestions for further research. Finally, Section 4 highlights the main implications of the study.

\section{Materials and Methods}

\subsection{Study Area}

The PUA of the GCR is located around the Greater Cairo core (main agglomeration) and extended in two governorates: Giza and Qalyoubia. The boundary of the PUA around the GCR has been defined by the World Bank in 2008 and Sims in 2011 [45,46] where it includes 10 municipalities (Marakiz). These municipalities are: El-Khanka, Shibeen Al-qanatir, Qaliub, Al-qanatir Al-khieriya, Embaba, Ousim, Kirdasa, Al-giza, Al-hawamdiya, and Al-badrashain, as shown in Figure 2.

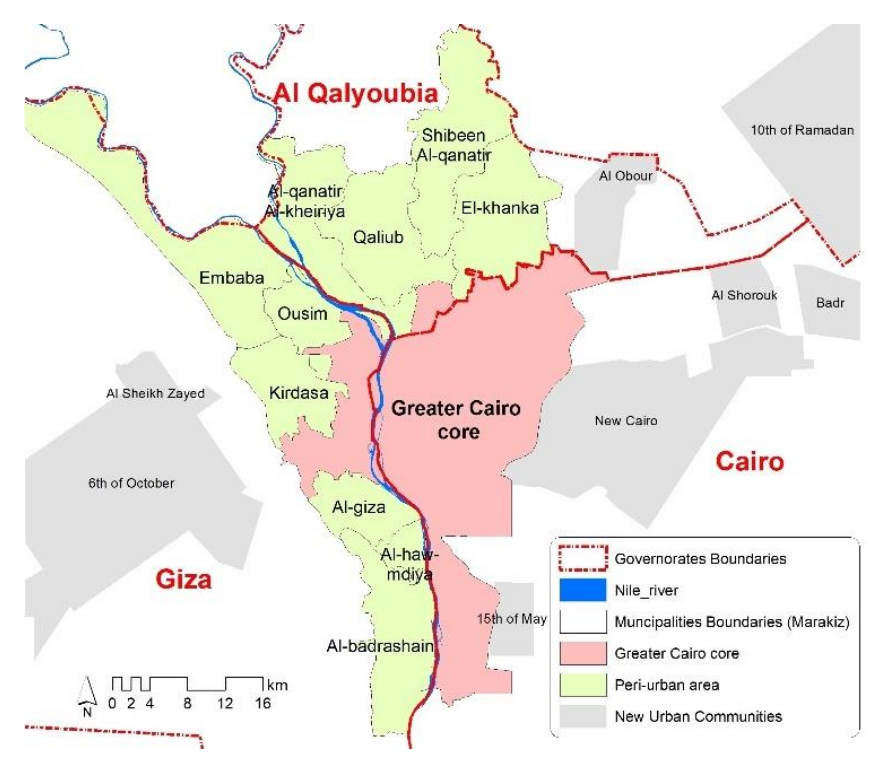

Figure 2. Study area. 
The PUA represents $35 \%$ of the total area of the GCR and more than $24 \%$ of the total population, approx. 4 million inhabitants [47-49], as shown in Table 1.

Table 1. Peri-urban area share of Greater Cairo region (GCR)'s area and population in 2006.

\begin{tabular}{ccccc}
\hline \multirow{2}{*}{ Greater Cairo } & \multicolumn{2}{c}{ Area } & \multicolumn{2}{c}{ Population } \\
\cline { 2 - 5 } & Area $\mathbf{( k m}^{2} \mathbf{)}$ & $\%$ & thousand & $\%$ \\
\hline Core Agglomeration & 507 & 17 & 11,748 & 72.1 \\
PUA (10 Markaz) & 1048 & 35 & 3942 & 24.2 \\
New Urban Community & 1414 & 48 & 602 & 3.7 \\
Total GCR & 2970 & 100 & 16,292 & 100 \\
\hline
\end{tabular}

Source: Census 2006.

The distances between these ten municipalities and the core of GCR range between 5 and $25 \mathrm{~km}$. Agriculture and related services are the main activity in most of these municipalities, all of which are made up of dense smallholder farms which depend on fruits and vegetables, mostly targeted at Greater Cairo markets. Industry is the main activity in the municipalities of El-Khanka and Shibeen $\mathrm{Al}$-qanatir, while trade is the main activity of Al-hawamdiya. Table 2 shows the main characteristics of each municipality.

Table 2. Main characteristics of PUAs' municipalities.

\begin{tabular}{|c|c|c|c|c|c|c|}
\hline \multirow{2}{*}{$\begin{array}{c}\text { PUA's }^{\prime} \text { tipalities } \\
\text { municipali }\end{array}$} & \multirow[t]{2}{*}{ Area $\left(\mathrm{km}^{2}\right)$} & \multirow[t]{2}{*}{ Main Activity } & \multicolumn{2}{|c|}{ Population (Thousand) } & \multirow{2}{*}{$\begin{array}{l}\text { Absolute } \\
\text { Increase }\end{array}$} & \multirow{2}{*}{$\begin{array}{c}\text { \%Growth } \\
\text { Rate }\end{array}$} \\
\hline & & & 1996 & 2006 & & \\
\hline El-Khanka & 128.3 & Industry & 459.0 & 726.8 & 267.8 & 4.70 \\
\hline Al-qanatir Al-khieriya & 93.8 & Agriculture & 296.7 & 381.4 & 84.7 & 2.54 \\
\hline Shibeen Al-qanatir & 140.6 & Industry & 338.6 & 421.9 & 83.3 & 2.22 \\
\hline Qaliub & 145.8 & Agriculture & 361.6 & 472.0 & 110.5 & 2.70 \\
\hline Al-hawamdiya & 20.9 & Trade & 115.4 & 140.5 & 25.2 & 1.99 \\
\hline Al-badrashain & 106.9 & Agriculture & 258.9 & 380.6 & 94.8 & 2.90 \\
\hline Ousim & 52.8 & Agriculture & 193.8 & 275.5 & 81.7 & 3.58 \\
\hline Embaba and Kirdasa * & 270.2 & Agriculture & 626.0 & 897.1 & 271.1 & 3.66 \\
\hline Giza & 56.5 & Agriculture & 180.6 & 246.3 & 65.8 & 3.15 \\
\hline Total municipalities & 1048 & & 2857.5 & 3942.3 & 1084.8 & 3.27 \\
\hline
\end{tabular}

Source: World Bank 2008, Censuses of 1996 and 2006, ${ }^{*}$ Embaba and Kirdasa were one unit in the census.

\subsection{Data}

This study extracted a set of indicators that have been used by international organizations, to utilize them in measuring and assessing the performance of sustainable development in the PUAs of GCR. Most indicators were derived from secondhand data, like the official censuses and international reports. A database was created based on the secondhand data and integrated in ArcGIS software to present the indicators data on a Greater Cairo map. The study used a time series over a period of 1996-2006 to explain the trend of changes. The values of the main agglomeration have been used as a benchmark for PUAs' municipalities to investigate the development challenges in the study area.

\subsection{Sustainable Development Indicators}

Sustainable development indicators (SDIs) are statistics that are used to measure the progress in all the dimensions of SD; social, economic, and environmental [25,31]. These indicators are an increasingly important tool with which to measure the progress toward achieving the SDGs [50-52]. SDIs aim to evaluate and benchmark SD conditions and trends across time and space, and monitor progress toward SDGs and their targets [22]. The need for applicable indicators to guide the SD process 
was recognized early, since the Earth Summit in 1992 [14]. Many international organizations, research institutes, and researchers have proposed various sets of indicators to assess the progress toward SD according to the level of study [6,14,25-30]. Nevertheless, Nagy et al. discussed the lacking of consensus regarding the optimal number of indicators needed to measure the performance of SD [4].

Plenty of attempts have been made to standardize SDI at various levels. The UN [53] has proposed a framework that includes 232 indicators to measure the progress toward SD, globally. The European Commission has prepared a framework of 14 indicators to assess the progress in attaining SD in European cities [16]. Kondyli [54] has developed a methodology to measure and evaluate SD at the regional level using 19 indicators. Tanguay et al [14] have developed an approach for selection SDI on city level based on 188 indicators, while Panda et al. have developed a framework to evaluate the progress of SD in the Indian cities using 37 indicators [24]. Diaz-Chavez [23] has proposed a list of 30 indicators for measuring SD at the local level in Mexico City [23]. Table 3 shows a summary of previous studies.

Table 3. Summary of previous studies.

\begin{tabular}{cccc}
\hline Reference & Level of Study & Location (If Applicable) & No. of Used Indicators \\
\hline UN [53] & Global/National & Global & 232 \\
Khalid et al. [51] & National & India & 25 \\
Carraro et al. [55] & National & - & 18 \\
Shaaban [22] & National & Egypt & 13 \\
European Commission [16] & Regional & European cities & 14 \\
Nagy et al. [4] & Regional & Romania & 39 \\
Kondyli [54] & Regional & Greece & 19 \\
Brugmann [56] & Local & USA & 10 \\
Tanguay et al. [14] & Local & - & 29 \\
Hu et al. & Local & China & 23 \\
Tang et al. & Local & China & 27 \\
Diaz-Chavez [23] & Local & Mexico City & 30 \\
Lu [57] & Local & China & 29 \\
Pires et al. [25] & Local & Portugal & 20 \\
Hu et al. & Local & China & 23 \\
Tang et al. & Local & China & 27 \\
Panda et al. [24] & Local & India & 37 \\
Zulaica [20] & Local & Argentina & 19 \\
Huang et al. [58] & Local & - & 10 \\
Mangi [5] & Local & China and Pakistan & 36 \\
Feng et al. [59] & Local & China & 52 \\
\hline
\end{tabular}

Nevertheless, Diaz-Chavez, Zulaica, and Nallathiga emphasized that most of the SDIs at the local level are not working with PUAs, due to the unique characteristics of PUAs as a mixture zone of urban and rural features $[20,23,60]$. In addition, Klopp, Nagy, and Arha discussed many challenges to applying these indicators in the PUAs $[4,7,31,32]$. Huang and Tanguay et al. also confirmed the difficulty of quantifying a group of indicators at the PUA level, due to unavailability of both information and strong data collection institutions in these areas $[14,58]$. Hence, this study developed an innovate framework of SDIs for measuring the progress towards SD in the PUAs of GCR in Egypt.

The study has defined the SDIs through four main steps. In the first step, the authors collected 81 of the indicators that have been used mainly at the local level during the previous studies and that cover the three aspects of SD. Of these indicators, 33 had been used once in a special case study. Therefore, these 33 indicators were discarded to reduce the list of indicators to 48 (second step). In addition, more than $30 \%$ (16 out of 48 indicators) of indicators had been frequently used during more than $50 \%$ of the chosen studies. However, if we had selected the indicators of frequency higher than $70 \%$ (i.e., used in more than 11 studies), we would have ended up with 7 indicators and they would not have included any of the environmental dimension. For this reason, we selected those indicators that had a frequency 
of more than $50 \%$ of the chosen studies which accounts for 16 indicators (third step). However, some of these indicators were not applicable to the study area, like Gini's coefficient. Hence, the fourth step was to filter the 16 indicators (the outcomes of the prior steps) against the three following criteria:

- Measurability: the indicator should be measurable at the PUA level.

- Availability: the indicator should be available for PUAs' municipalities.

- Dynamics: the indicator should be available for two different years at least to detect the changes during a period.

In addition, the selected indicators had to cover the three dimensions of SD and be relevant to 17 SDGs. Consequently, the study found 13 indicators could be utilized to measure the progress towards the SD in the study area. Figure 3 shows the methodology of study; a schematic diagram of our selection approach, which proceeded in four steps, and the distribution of the selected indicators to sustainable development aspects.

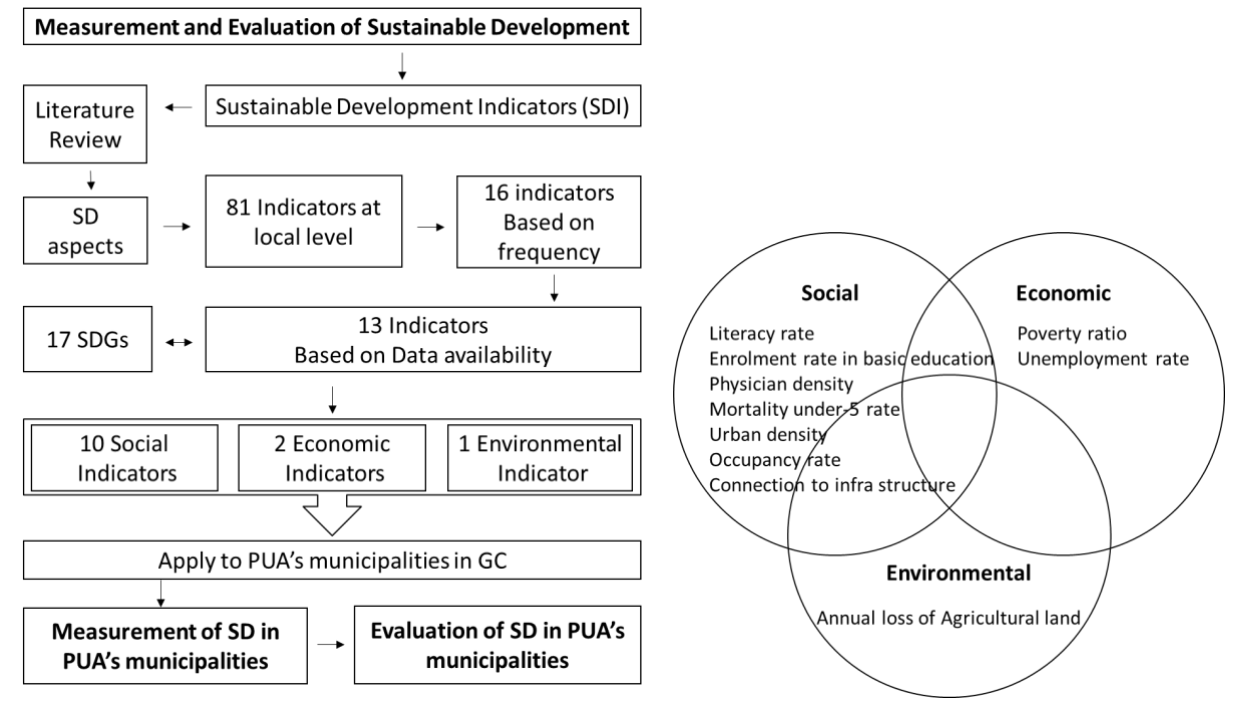

Figure 3. Methodology of study.

Table 4 shows the chosen indicators for this study.

Table 4. The chosen indicators for this study.

\begin{tabular}{|c|c|c|}
\hline Indicators & Relevant SDGs & Source \\
\hline Poverty ratio (\% of population) & Goal 1 (No Poverty) & World Bank \\
\hline Physician density (per 1000 people) & \multirow{2}{*}{ Goal 3 (Good Health) } & UNICEF \\
\hline $\begin{array}{l}\text { Mortality rate, under-5 } \\
\text { (per } 1000 \text { live births) }\end{array}$ & & WHO \\
\hline $\begin{array}{l}+15 \text { Literacy rate }(\%) \\
\% \text { Total enrolment rate in basic education }\end{array}$ & Goal 4 (Quality of Education) & UNESCO \\
\hline$\%$ Female enrolment rate in basic education & Goal 5 (Gender Equality) & WEF/UNESCO \\
\hline $\begin{array}{c}\% \text { Households connected to the water } \\
\text { network }\end{array}$ & Goal 6 (Clean Water and & WDI/WHO/UN \\
\hline $\begin{array}{l}\% \text { Households connected to the sanitation } \\
\text { network }\end{array}$ & Sanitation) & HABITAT \\
\hline $\begin{array}{c}\% \text { Households connected to electricity } \\
\text { network }\end{array}$ & Goal 7 (Affordable Energy) & WDI/World Bank \\
\hline Unemployment rate (\% of total labour force) & Goal 8 (Decent Work) & IMF WEO \\
\hline $\begin{array}{l}\text { Urban density } \\
\text { Occupancy rate }\end{array}$ & Goal 11 (Sustainable Communities) & OECDUN HABITAT \\
\hline Annual loss of agriculture lands & Goal 15 (Life on Land) & FAO \\
\hline
\end{tabular}


We acknowledge the fact that data available on the municipality level were an issue, especially related to the SDGs 9, 10,12,13,14,16, and 17, where indicators related to these goals are only available on the higher levels or do not exist at the study area. The study used a time series throughout 1996-2006 to explain the trend of change, and to thus evaluate the sustainable development in the study area.

\section{Results and Discussion}

\subsection{Measuring Sustainability in the PUA}

\subsubsection{Literacy Rate}

The study results show that the total $(15+)$ literacy rate in all PUAs stood at $62.8 \%$ in 1996 and increased to $66.8 \%$ in 2006 . The highest rate of $(15+)$ literacy in 2006 was in Kerdasa municipality where it reached $71 \%$, while the lowest rate was in Al-badrashain municipality where it reached $48.4 \%$. On the other hand, $(15+)$ literacy rate in the core agglomeration reached $78.9 \%$ in 1996 and increased to $80.7 \%$ in 2006. Table 5 and Figure 4 show the changes in (+15) literacy rate in PUAs and core agglomeration from 1996 to 2006.

Table 5. The Changes Of (+ 15) Literacy Rate in the PUAs And Core Agglomeration From 1996 to 2006.

\begin{tabular}{ccc}
\hline Municipalities (Marakiz) & $\mathbf{\% ( 1 5 + )}$ Literacy $\mathbf{1 9 9 6}$ & $\mathbf{\%} \mathbf{( 1 5}+\mathbf{)}$ Literacy $\mathbf{2 0 0 6}$ \\
\hline Al-badrashain & 57.9 & 58.4 \\
Al-giza & 59.3 & 62.5 \\
Al-hawamdiya & 70.8 & 70.3 \\
Al-khanka & 64.7 & 70 \\
Al-qanatir Al-kheiriya & 62.2 & 68.6 \\
Embaba & 63.2 & 63.7 \\
Kirdasa & 63.2 & 71 \\
Ousim & 62.6 & 67.7 \\
Qaliub & 60.6 & 64.8 \\
Shibeen Al-qanatir & 63.6 & 70.7 \\
Total PUA & 62.8 & 66.8 \\
Core Agglomeration & 78.9 & 80.7 \\
\hline
\end{tabular}

Source: Censuses of 1996 and 2006.

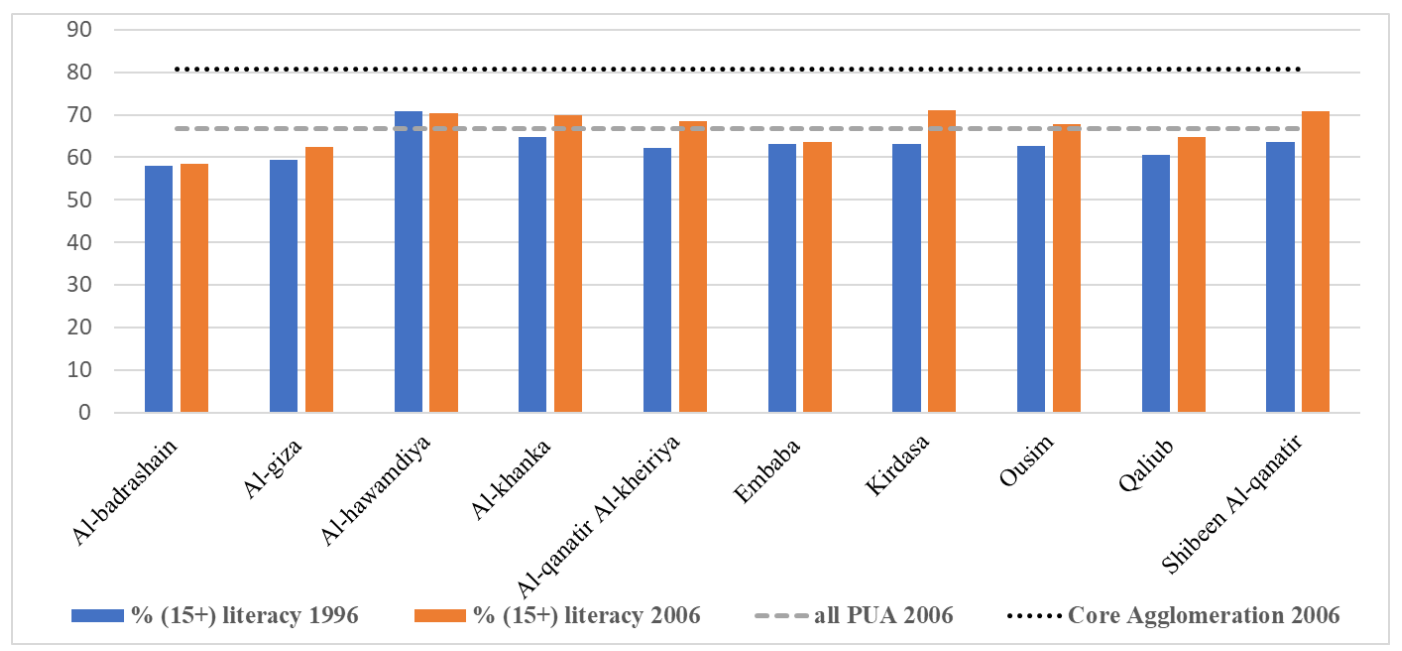

Figure 4. The changes in literacy rate.

It is notable that most of the municipalities in which agriculture is the main activity had a high percentage of literacy. The reason for that might be the lack of interest in this issue by farmers. 


\subsubsection{Enrolment Rate in Basic Education}

The study results show that the total enrollment rate in basic education in all PUAs stood at $76.5 \%$ in 1996 and increased to $81.2 \%$ in 2006. The highest enrollment rate in basic education in 2006 was in the Al-hawamdiya municipality, where it reached $88.9 \%$, while the lowest rate was in Al-giza municipality where it reached $72.6 \%$. Meanwhile, the enrollment rate in basic education in the core agglomeration reached 81.2\% in 1996 and increased to 88.4\% in 2006, as shown in Table 6 and Figure 5.

Table 6. The changes of enrollment rate in basic education in the PUAs.

\begin{tabular}{ccc}
\hline \multirow{2}{*}{ Municipalities (Marakiz) } & \multicolumn{2}{c}{ \% Total Enrollment Rate in Basic Education } \\
\cline { 2 - 3 } & $\mathbf{1 9 9 6}$ & $\mathbf{2 0 0 6}$ \\
\hline Al-badrashain & 71 & 77.3 \\
Al-giza & 71.3 & 72.6 \\
Al-hawamdiya & 72.7 & 88.9 \\
Al-khanka & 87.3 & 88 \\
Al-qanatir Al-kheiriya & 85.2 & 82 \\
Embaba & 69 & 74.7 \\
Kirdasa & 69 & 72.5 \\
Ousim & 93 & 84.5 \\
Qaliub & 63.4 & 83 \\
Shibeen Al-qanatir & 83.5 & 88 \\
Total PUA & 76.5 & 81.2 \\
Core Agglomeration & 89.1 & 88.4 \\
\hline
\end{tabular}

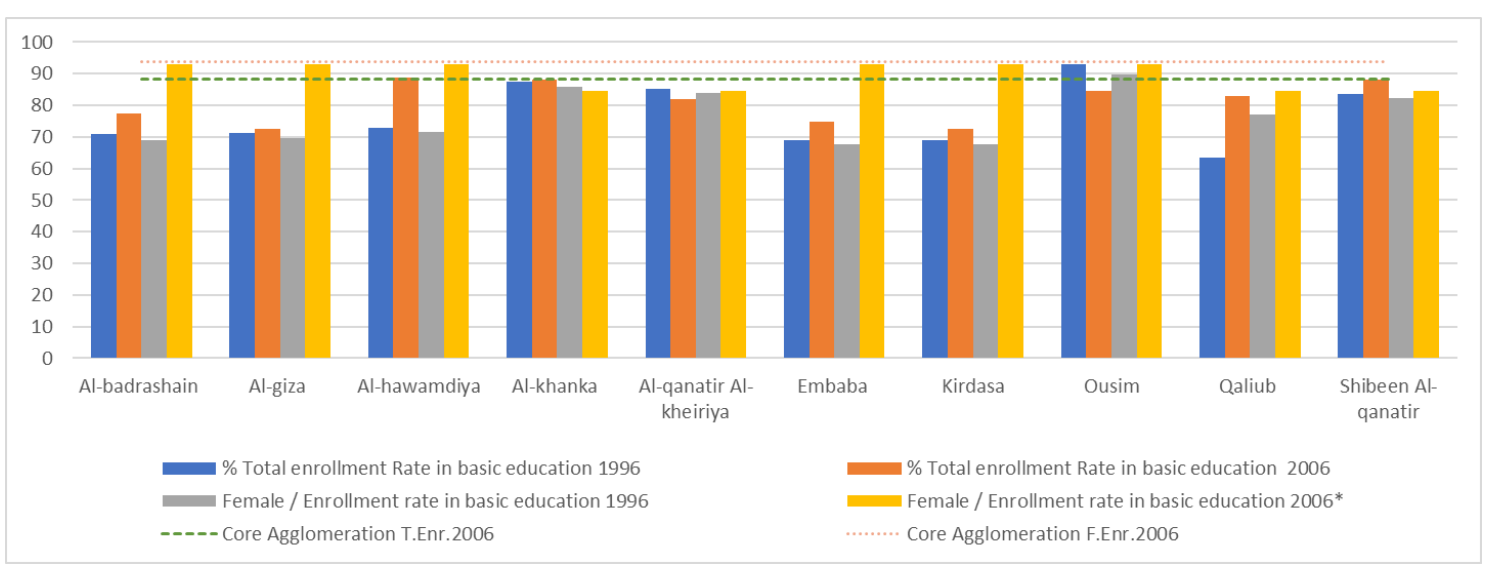

Figure 5. The changes in enrollment rates in basic education.

It is notable that the spreading of schools in the core agglomeration has played a clear role in increasing the enrollment rate in basic education in the city, rather than in the PUAs' municipalities.

\subsubsection{Enrollment Rate in Basic Education for Women and Girls}

As for the enrollment rates in basic education for women and girls in the PUA, the rates were better than the total enrollment rates, where they reached $76.4 \%$ of the total population of women and girls in the corresponding age group in 1996 and increased to 89.6\% in 2006. However, there is still a gap between PUAs and core agglomeration, where the rates in the core agglomeration reached $87.1 \%$ in 1996 and increased to $93.8 \%$ in 2006. Table 7 and Figure 5 show the changes in women and girls' enrollment rates in basic education in the PUAs and in core agglomeration from 1996 to 2006.

There was a noticeable improvement in the enrollment rates for women and girls in 2006, especially in Embaba and Kirdasa municipalities, where the rates increased from $67.5 \%$ in 1996 to $93 \%$ in 2006. The main reason for this improvement might be due to the government attention to the education 
of women and since launching the Millennium Development Goals (MDGs). However, the level of enrollment in the city may be better than the levels in the PUAs due to increasing awareness of families in the city, as opposed to thaose in the PUAs.

Table 7. \% Enrollment rate in basic education for women and girls.

\begin{tabular}{ccc}
\hline \multirow{2}{*}{ Municipalities (Marakiz) } & \% Enrollment Rate in Basic Education for Women and Girls \\
\cline { 2 - 3 } & $\mathbf{1 9 9 6}$ & $\mathbf{2 0 0 6}$ \\
\hline Al-badrashain & 69.1 & 93 \\
Al-giza & 69.6 & 93 \\
Al-hawamdiya & 71.7 & 93 \\
Al-khanka & 85.9 & 84.6 \\
Al-qanatir Al-kheiriya & 83.8 & 84.6 \\
Embaba & 67.5 & 93 \\
Kirdasa & 67.5 & 93 \\
Ousim & 89.6 & 93 \\
Qaliub & 77.1 & 84.6 \\
Shibeen Al-qanatir & 82.2 & 84.6 \\
Total PUAs & 76.4 & 89.64 \\
Core Agglomeration & 87.1 & 93.8 \\
\hline
\end{tabular}

\subsubsection{Physician Density}

The analysis outcomes show that physician density in all PUAs stood at 0.3 physicians per 1000 people in 2010. This rate is very low, especially compared to the rate in the core agglomeration where it reached 1.2 physicians per 1000 people. The highest physician density was in Al-hawamdiya municipality where it reached 0.9 physicians per 1000 people, while the lowest rate was in the Al-badrashain, Al-khanka, Embaba, and Ousim municipalities where it reached 0.2 physicians per 1000 people, as shown in Table 6. It is noteworthy to mention that the physician density in the European countries exceeds 3 physicians per 1000 people [61].

\subsubsection{Under-5 Mortality Rate}

The under-5 mortality rate underwent a remarkable decline during the period 2003-2010, especially in the Qaluib municipality, where it decreased from 50.5 deaths per 1000 live births in 2003 to 15.5 deaths per 1000 live births in 2010. In addition, the overall average of the under-5 mortality rates in all PUAs became better than the core agglomeration according to the world bank report in 2010, as shown in Table 8.

Table 8. The physician density and the change in under-5 mortality rates in PUAs' municipalities.

\begin{tabular}{cccc}
\hline $\begin{array}{c}\text { Municipalities } \\
\text { (Marakiz) }\end{array}$ & $\begin{array}{c}\text { Number of Physicians/1000 } \\
\text { Person 2010 }\end{array}$ & $\begin{array}{c}\text { Under-5 Mortality } \\
\text { Rate 2003 }\end{array}$ & $\begin{array}{c}\text { Under-5 Mortality } \\
\text { Rate 2010 }\end{array}$ \\
\hline Al-badrashain & 0.2 & 24.9 & 16.2 \\
Al-giza & 0.3 & 24.1 & 16.2 \\
Al-hawamdiya & 0.9 & 21.7 & 16.2 \\
Al-khanka & 0.2 & 21.1 & 15.5 \\
Al-qanatir Al-kheiriya & 0.4 & 24.2 & 15.5 \\
Embaba & 0.2 & 26.2 & 16.2 \\
Kirdasa & 0.3 & 21.8 & 16.2 \\
Ousim & 0.2 & 24.7 & 16.2 \\
Qaliub & 0.3 & 50.5 & 15.5 \\
Shibeen Al-qanatir & 0.4 & 28.1 & 15.5 \\
total PUAs & 0.3 & 26.7 & 15.9 \\
Core Agglomeration & 1.2 & 24.3 & 22.4 \\
\hline
\end{tabular}

Source: World Bank report of Egyptian governorates in 2003\& 2010 


\subsubsection{Poverty}

As shown in Figure 6, across the PUAs' municipalities in general, the percentage of people living under the poverty line is very high.

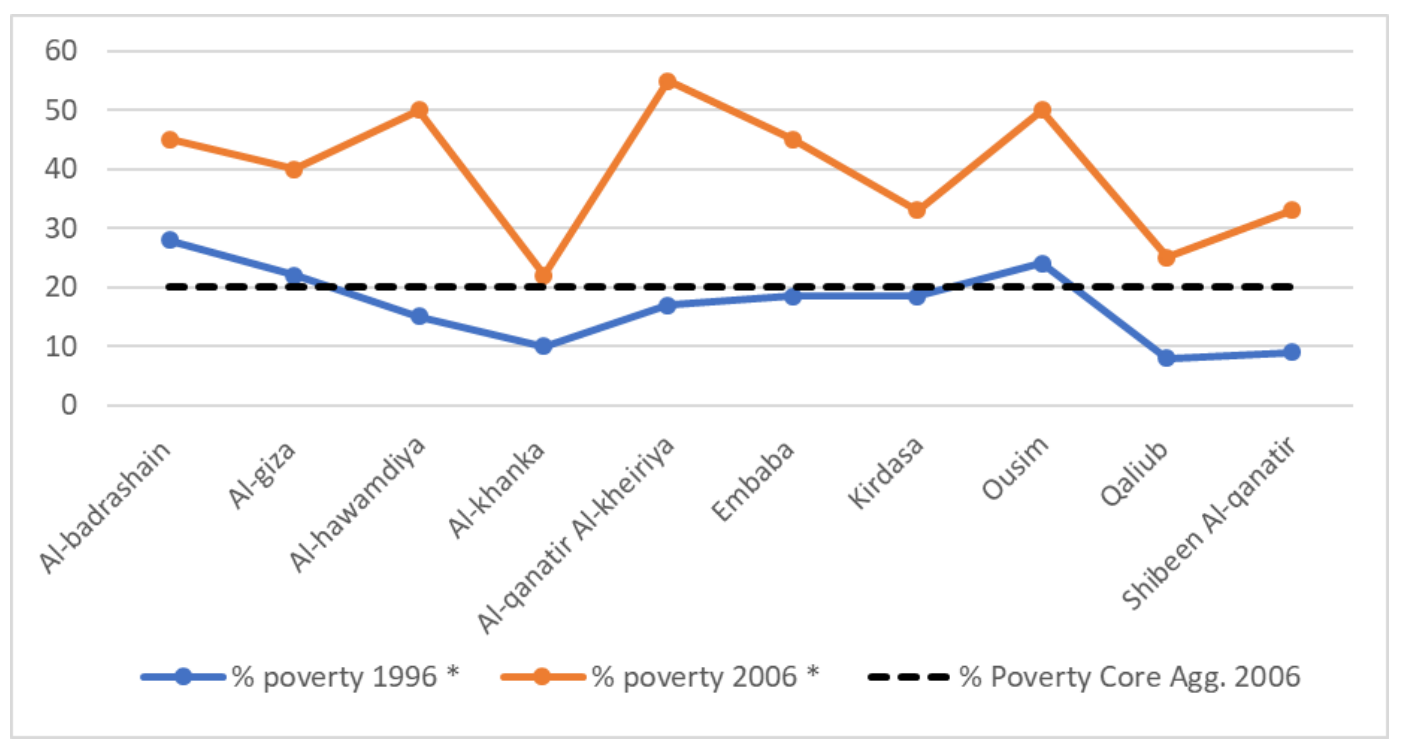

Figure 6. Poverty in the PUAs municipalities (\%).

Moreover, only two of the ten PUA municipalities are above the national average, and when compared to the core agglomeration, PUAs' municipalities are significantly poorer, especially those located in the west in Giza Governorate.

\subsubsection{Unemployment Rate}

The indicator of unemployment rate refers to a negative change where the percentages of unemployment had increased from 1996 to 2006 in all PUAs' municipalities. Figure 7 shows the change of unemployment rate from 1996-2006.

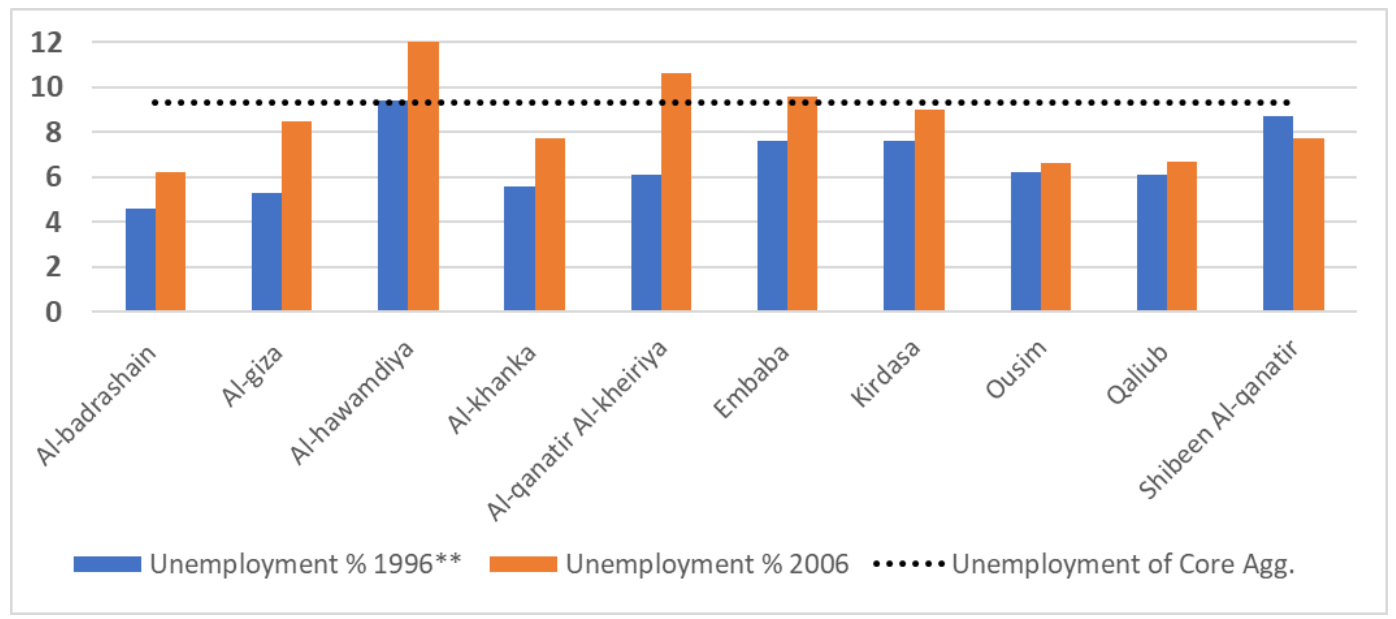

Figure 7. Unemployment rate in the PUAs' municipalities.

It is worth mentioning that most of the employed population in the PUAs are working in the core agglomeration, due to the concentration of job opportunities there. In this regard, Denis and Vignal estimated that $43 \%$ of public jobs and $40 \%$ of private jobs in Egypt, in 2006, were concentrated in the core agglomeration of Cairo [62]. 


\subsubsection{Urban Density}

Urban density measures the number of people who are living in a specific urban area. According to planning law in Egypt (Law no.3 of 1982), the urban density should not exceed 150 people per feddan in rural villages or 250 people per feddan in urban cities. So, the urban densities in the PUAs' municipalities are considered extremely high, except in Al-khanka and Shibeen Al-qanatir municipalities, as shown in Figure 8.

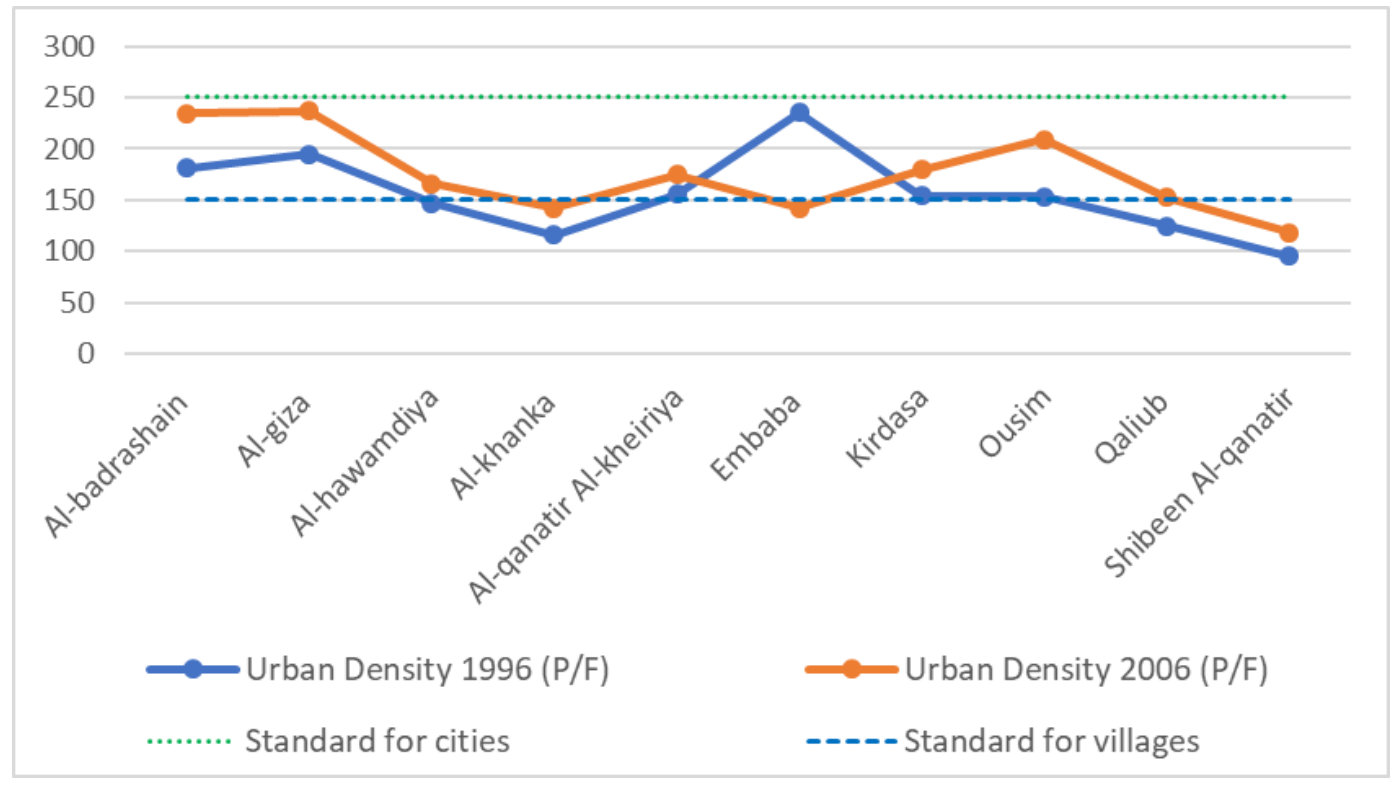

Figure 8. Urban density in the PUAs' municipalities.

\subsubsection{Occupancy Rate}

Occupancy rate is considered one of the major elements affecting human health [63]. A high occupancy rate of persons in a small space promotes the rapid spread of infection, especially among children (WHO, 2010). Based on the quantitative analysis of the occupancy data calculated by CAPMAS in 1996 and 2006, the total occupancy rate in all PUAs decreased from 1.4 to 1.2 people per room, respectively, as shown in Figure 9.

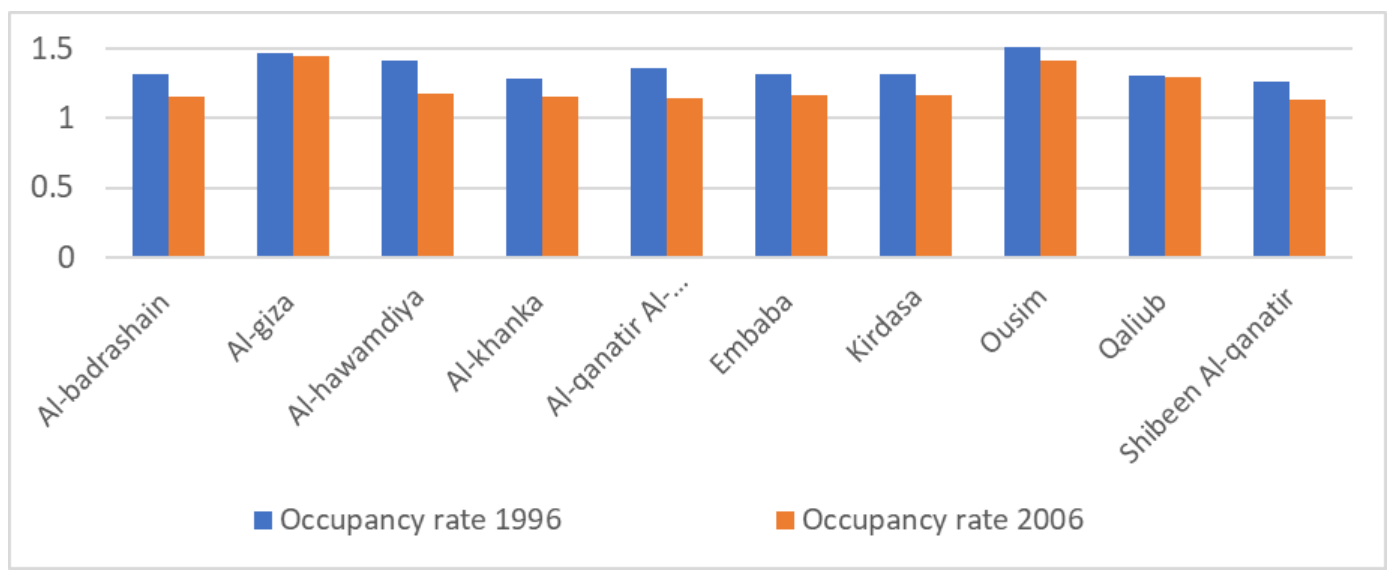

Figure 9. Occupancy rate in the PUAs' municipalities.

The reason for this decline is most probably because of the increasing numbers of vacant houses in the PUAs due to real estate speculation in these areas.

In the last census, the percentage of vacant houses $22.7 \%$ of the total number of apartments. 


\subsubsection{Electricity Access}

The analysis outcomes indicate that more than $95 \%$ of households in the PUAs' municipalities had access to the public electricity network in 1996, and that this percentage exceeded $99 \%$ in 2006 ; so all PUA's municipalities recorded high scores in this indicator, as shown in Figure 10.

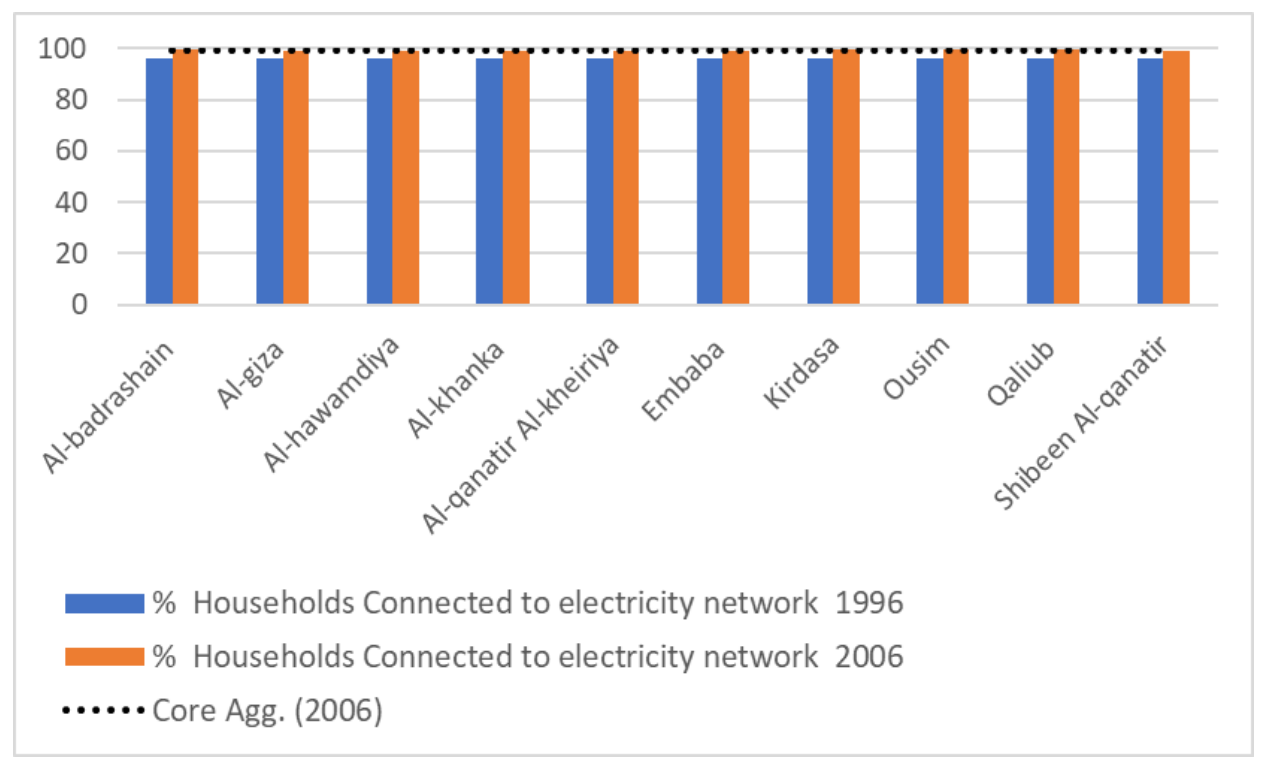

Figure 10. Connection to the electricity network in the study area.

\subsubsection{Water Access}

According to the official census, over $68 \%$ of households in PUAs' municipalities had access to the public water network in 1996. This figure reached $92 \%$ in 2006, as shown in Figure 11. However, recent research argues that wide areas in PUAs' municipalities still suffer from problems related to the quantity, quality, and accessibility of water during the daytime in particular [64].

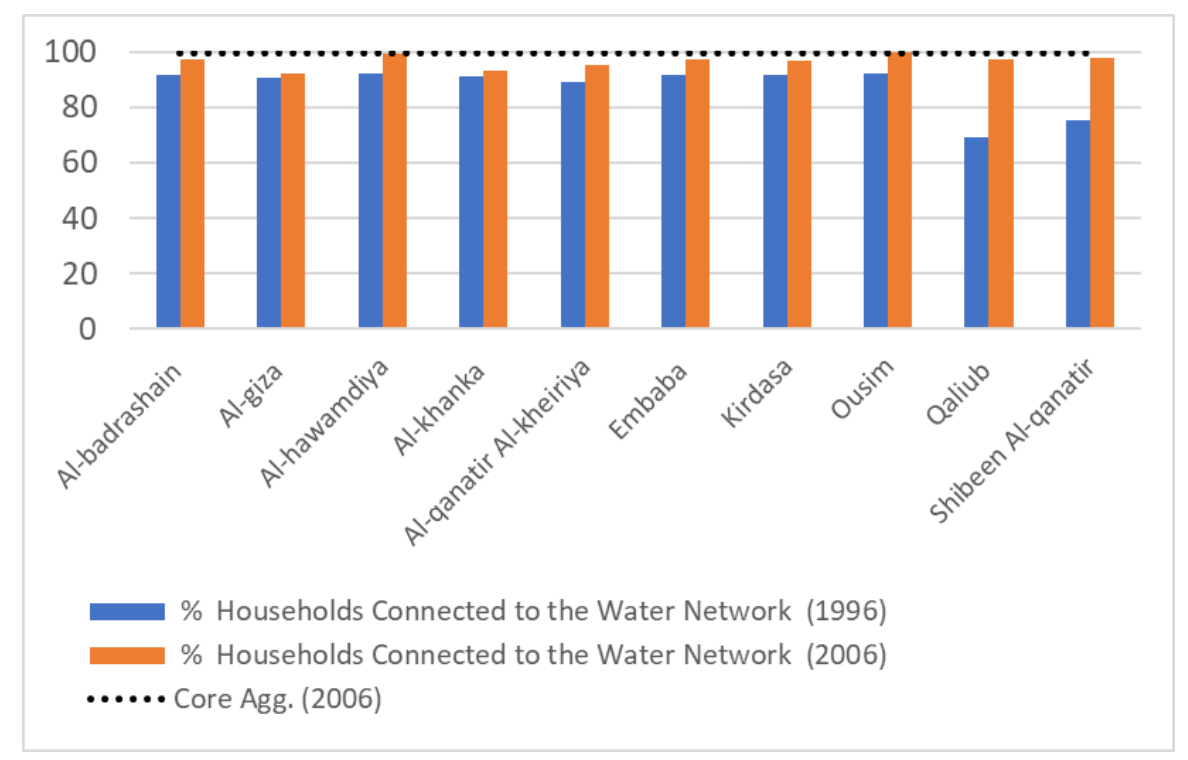

Figure 11. Connection to water network. 


\subsubsection{Sanitation Access}

While access to electricity and water exceeds 95\% in the PUAs, the sanitation connections are quite different. The results show that most of the households in PUAs municipalities do not have access to the public sanitation network, as shown in Figure 12. The households in these municipalities use septic tanks as an alternative to the public network. Unfortunately, septic tanks leak sewage into the ground water, which affects the health of residents [64]. In addition, due to the deteriorated status of pipes transporting water in these municipalities, sewage from septic tank leakage may even pollute the water supply. The leakage from septic tanks also threats the structural safety of nearby buildings, posing additional hazards to inhabitants.

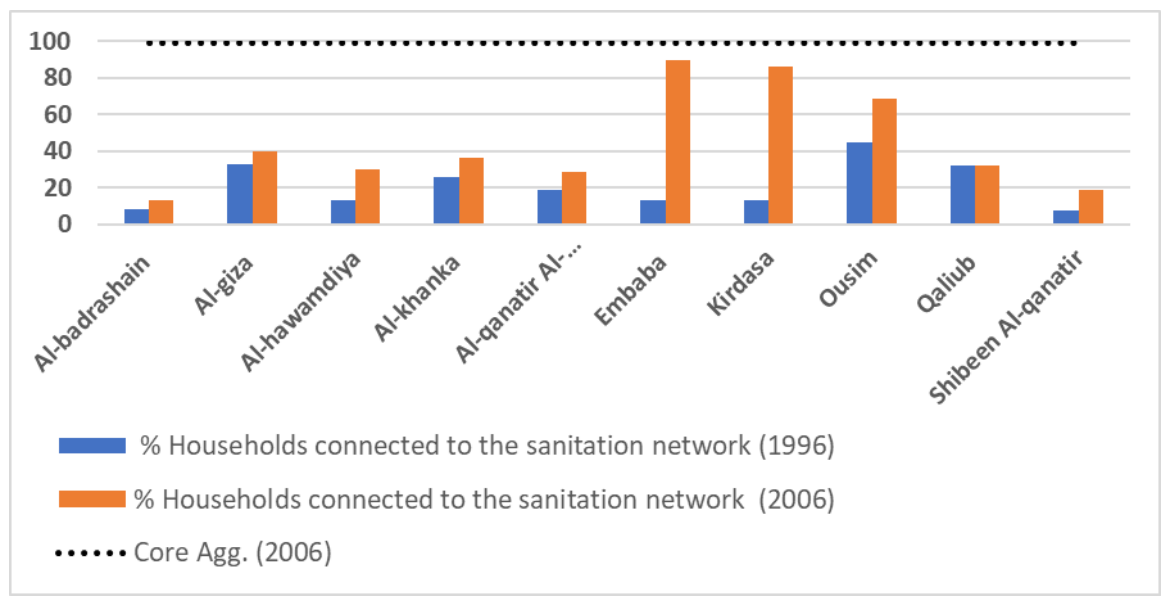

Figure 12. Connection to sanitation in the study area.

Although since 2006 the government has worked to increase the number of households who have access to the public sanitation network, the percentage is still very low and the gap still very wide between the core agglomeration and PUAs' municipalities.

\subsubsection{Annual Loss of Agricultural Land}

The annual loss of agricultural land in all PUAs of GCR is considered the highest one in Egypt [65], where the average loss exceeded $9 \%$ of the total agricultural land per year, especially in the northern parts of Al-qantir Al-kheiriya and Qaluib [47,66,67]. Figure 13 shows the annual loss of agricultural land in the study area over the period 1996-2006.

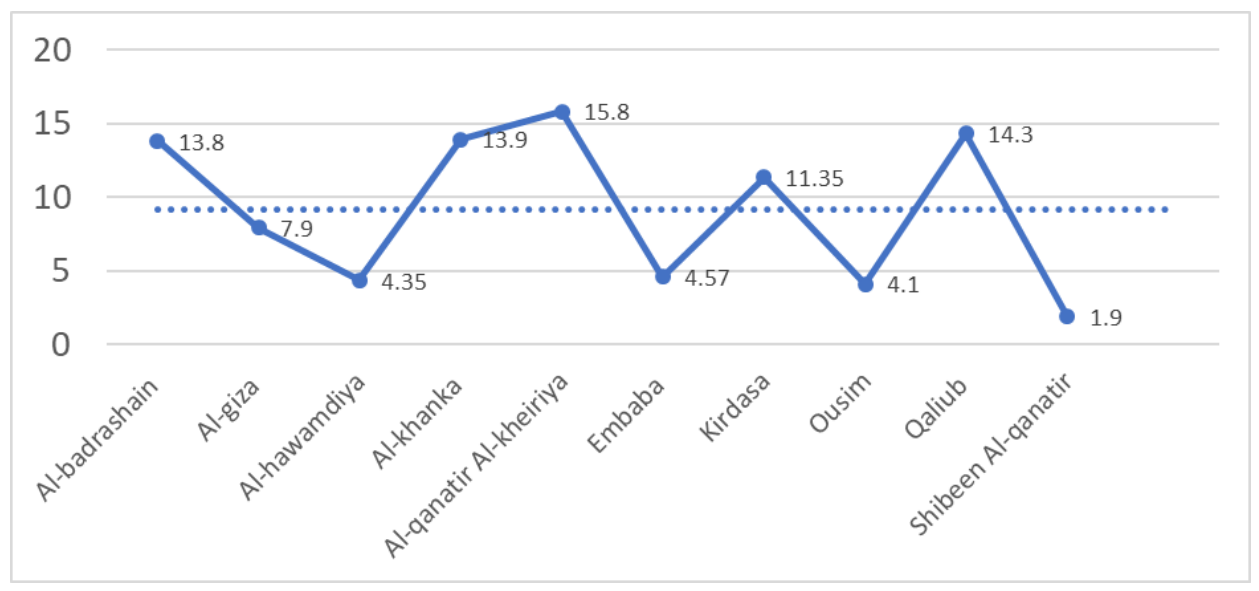

Figure 13. The annual loss of agricultural land in the study area over the period 1996-2006. 


\subsection{Evaluation of Sustainable Development in the PUAs Municipalities}

Based on the literature review and the data properties, benchmarking normalization was employed to remove the scale effects of various indicator units [12,24,55]. Benchmark values for each indicator were assigned according to their minimum and maximum impacts on sustainable development, as shown in Table 9.

Table 9. The score of evaluation of sustainable development in the PUAs municipalities.

\begin{tabular}{|c|c|c|c|c|c|c|c|c|c|c|c|c|c|c|}
\hline Municipalities & 1 & 2 & 3 & 4 & 5 & 6 & 7 & 8 & 9 & 10 & 11 & 12 & 13 & Total \\
\hline Al-badrashain & & & & & & & & & & & & & & 19 \\
\hline Al-giza & & & & & & & & & & & & & & 17 \\
\hline Al-hawamdiya & & & & & & & & & & & & & & 26 \\
\hline Al-khanka & & & & & & & & & & & & & & 25 \\
\hline Al-qanatir Al-kheiriya & & & & & & & & & & & & & & 24 \\
\hline Embaba & & & & & & & & & & & & & & 21 \\
\hline Kirdasa & & & & & & & & & & & & & & 24 \\
\hline Ousim & & & & & & & & & & & & & & 23 \\
\hline Qaliub & & & & & & & & & & & & & & 23 \\
\hline Shibeen Al-qanatir & & & & & & & & & & & & & & 30 \\
\hline
\end{tabular}

Each indicator has been expressed with a score ranging between 1 and 3: (1) indicates low performance (unsustainable condition/red color); (2) indicates medium performance (need more effort to reach satisfactory level of sustainability/yellow color); (3) indicates high performance (satisfactory level of sustainability/green color). Figure 14 shows a classification of municipalities according to indicators of sustainability evaluation.

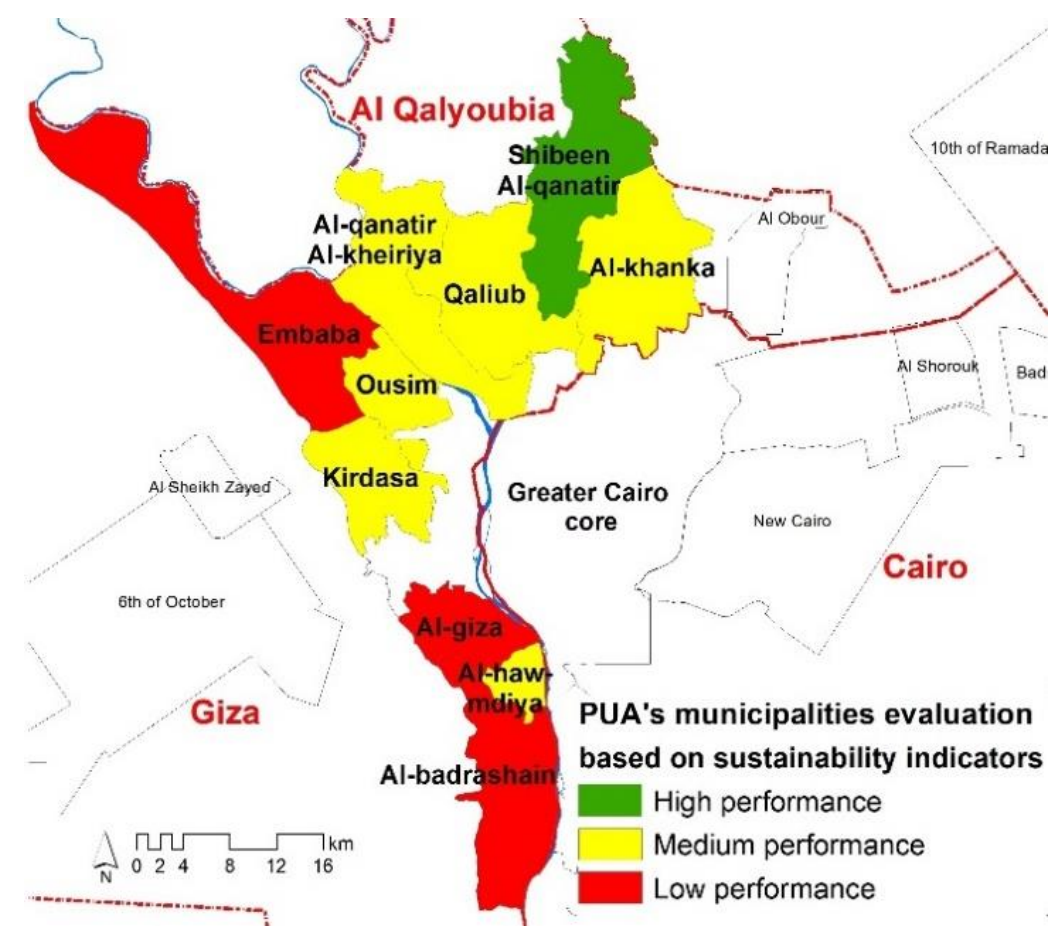

Figure 14. Classification of municipalities according to indicators of sustainability evaluation.

The evaluation outcomes show those municipalities which achieved progress towards sustainability and those which are still lagging. The Shibeen Al-qanatir municipality recorded the highest progress towards sustainability, while the municipalities of Embaba, Al-giza, and Al-badrashain recorded the lowest progress. The map shows that the farthest municipalities from core agglomeration 
recorded the lowest progress towards the sustainability, which proves the cruciality of the spatial dimension in the development process in the GCR.

The trend of attained development in the PUAs' municipalities might refer to improvement in the status of SD. However, this improvement might not reflect the expected status in these areas as long the government continues focusing on the urban area only in its development plans.

The government should include PUAs in Greater Cairo in its plans and enhance the infrastructure projects in these areas to decrease the current gap between PUAs and the core agglomeration.

The methodology of this study can be utilized for evaluating the progress in SD in any PUA in other countries. According to $\mathrm{Lu}$ [57], a good indicator framework can help local authorities to make significant decisions, and to assess the progress towards SDGs. In this regard, a national database including all the relevant information on PUAs municipalities in Egypt should be established.

Using the historical trend for SDIs in this study would help the local government of PUAs' municipalities to self-check their own development pathways and identify the main aspects that impede SD. Thus, they can recognize their strengths and weaknesses and then prepare the required policies for addressing the urban challenges.

The main strength of these analyses lies in the development of a framework to monitor and measure the progress towards SD in the PUAs, which have been marginalized for a long time. Despite the functional and spatial importance of PUAs in the GCR, this study is considered one of the first initiatives to understand and measure the states of SD in those areas.

\subsection{Data Limitations}

Despite constant efforts to enhance the results of measuring and evaluating SD within the PUAs, several limitations have arisen. Shortages of or missing data at the PUA level have led to decreasing the number of indicators that have been used. The SDIs in this study extensively relied on the census data released every 10 years, which is a useful tool for long term evaluation only. In addition, the limited number of indicators related to some SD aspects might affect the results of the study. Moreover, the use of equal weights for all indicators could also influence the evaluation of PUA's municipalities. Therefore, using more indicators and recent data could improve the precision of the results of this study. However, we are confident that in spite of these limitations, the research methodology can be widely applied in similar spatial contexts in other developing countries.

Comparing the results of this study with previous studies, we found that even though a few studies addressed SD at the local level in Egypt and other developing countries, this study remains one of the few studies that have assessed progress in attaining the SD on the PUAs' municipalities. For instance, Baseera [68] has assessed the progress toward SD at in Egyptian governorates (regional scale); therefore the PUAs' municipalities were neglected.

In terms of other developing countries, Nallathiga et al [60] have discussed the progress toward SD in PUAs of Delhi, India. However, they discussed the issue in the prospective of unstainable urbanization and haphazard development without presenting comprehensive indicators for measuring municipalities there. Diaz-Chavez [23] has proposed a list of 30 indicators for measuring SD in PUAs of Mexico City, using data from one specific date, which measure the state of SD in PUAs in that year only and do not produce an assessment for the progress toward SD in these areas.

Future work should be directed to develop this framework and discuss the best approaches to develop the current state of PUAs' municipalities. In addition, there is a need for further research into planning mechanisms which would enhance the development in the PUAs, particularly in the municipalities that witness a weak performance toward SD.

\section{Conclusions}

This study sought to evaluate the sustainability performance in the PUAs of GCR using the most important 13 indicators extracted from the literature review and international experiences. The main aim of this study was to develop an innovation framework for SDIs to assess the progress towards 
the SD in the PUAs of GCR. The study presented the outcomes of the analysis in a set of diagrams showing the progress of sustainable performance in each municipality. The classification of PUAs' municipalities based on the overall score of those indicators was one of the most important outcomes of this research. The results showed that the PUAs' municipalities slowly narrowed the gap between themselves and the core agglomeration in terms of SDIs over the period 1996-2006. Yet, a wide gap between PUAs' municipalities and the core agglomeration still exists, especially for both sanitation and education indicators. This study can help urban planners and decision-makers to better recognize the underdeveloped municipalities, and to thus work on developing the appropriate strategies and policies to improve the SD in such areas. Although the study faced some limitations, especially in terms of available data and the number of SDIs, the study tried to overcome this limitation to measure and evaluate the SD on the PUA level in the GCR. Future works need to focus on discussing the most appropriate approaches to improve the current state of sustainability in the PUAs' municipalities.

Author Contributions: M.S. wrote the original manuscript; N.T. and P.D. revised the paper; E.K. developed the methodology. All authors have read and agreed to the published version of the manuscript.

Funding: The initial draft was funded by Kyushu university, Japan and the full manuscript was funded by Ministry of Higher Education, Egypt.

Acknowledgments: This work would not have been possible without the financial support of the Egyptian Government and Cultural Affairs \& Missions Sector by funding this research. So that we give them all our deep thanks for this support.

Conflicts of Interest: The authors declare no conflict of interest.

\section{References}

1. Spangenberg, J.H. Scenarios and Indicators for Sustainable Development: Towards a Critical Assessment of Achievements and Challenges. Sustainability 2019, 11, 942. [CrossRef]

2. McInnes, R.J. Sustainable Development Goals. Wetl. Book I Struct. Funct. Manag. 2018, 631-636. [CrossRef]

3. UN. Global Indicator Framework for the Sustainable Development Goals; UN: New York, NY, USA, 2017.

4. Nagy, J.A.; Benedek, J.; Ivan, K. Measuring Sustainable Development Goals at a Local Level: A Case of a Metropolitan Area in Romania. Sustainability 2018, 10, 3962. [CrossRef]

5. Mangi, M.Y.; Yue, Z.; Kalwar, S.; Ali Lashari, Z. Comparative Analysis of Urban Development Trends of Beijing and Karachi Metropolitan Areas. Sustainability 2020, 12, 451. [CrossRef]

6. Lützkendorf, T.; Balouktsi, M. Assessing a Sustainable Urban Development: Typology of Indicators and Sources of Information. Procedia Environ. Sci. 2017, 38, 546-553. [CrossRef]

7. United Nations. Sustainable Development Challenges; United Nations: New York, NY, USA, 2013.

8. Wandl, A.; Magoni, M. Sustainable Planning of Peri-Urban Areas: Introduction to the Special Issue. Plan. Pract. Res. 2017, 32, 1-3. [CrossRef]

9. Keivani, R. A Review of the Main Challenges to Urban Sustainability. Int. J. Urban Sustain. Dev. 2010, 1, 5-16. [CrossRef]

10. Marshall, F.; Waldman, L.; MacGregor, H.; Mehta, L.; Randhawa, P. On the Edge of Sustainability: Perspectives on Peri-Urban Dynamics. Urban Geogr. 2009, 29, 1-72. [CrossRef]

11. James, P. Urban Sustainability in Theory and Practice; Paul, W., Ed.; Routledge: England, UK, 2014. [CrossRef]

12. Dizdaroglu, D. Developing Micro-Level Urban Ecosystem Indicators for Sustainability Assessment. Environ. Impact Assess. Rev. 2015, 54, 119-124. [CrossRef]

13. Huang, S.-L.; Wong, J.-H.; Chen, T.-C. A Framework of Indicator System for Measuring Taipei's Urban Sustainability. Landsc. Urban Plan. 1998, 42, 15-27. [CrossRef]

14. Tanguay, G.A.; Rajaonson, J.; Lefebvre, J.F.; Lanoie, P. Measuring the Sustainability of Cities: An Analysis of the Use of Local Indicators. Ecol. Indic. 2010, 10, 407-418. [CrossRef]

15. Nilsson, K.; Pauleit, S.; Bell, S.; Aalbers, C.; Nielsen, T.S. eri-Urban Futures: Scenarios and Models for Land Use Change in Europe. In Peri-Urban Futures: Scenarios and Models for Land use Change in Europe; Springer Science \& Business Media: Berlin, Germany, 2013; Volume 9783642305, pp. 1-453. [CrossRef]

16. European Commission. Indicators for Sustainable Cities; European Commission: Brussels, Belgium, 2018; Volume 2015. [CrossRef] 
17. UN Habitat. State of the World's Cities; UN Habitat: Nairobi, Kenya, 2013. [CrossRef]

18. Michalos, A.C. Sustainability Measurement. In Encyclopedia of Quality of Life and Well-Being Research; Springer: Dordrecht, The Netherlands, 2014; p. 6496. [CrossRef]

19. Weiland, U.; Kindler, A.; Banzhaf, E.; Ebert, A.; Reyes-Paecke, S. Indicators for Sustainable Land Use Management in Santiago de Chile. Ecol. Indic. 2011, 11, 1074-1083. [CrossRef]

20. Zulaica, M.L. Is Mar Del Plata (Argentina) a Sustainable City? An Evaluation of the Sustainability of Urban and Peri-Urban Areas Using Indicators. Sustentabilidade em Debate 2019, 10, 10-27. [CrossRef]

21. Mensah, J. Sustainable Development: Meaning, History, Principles, Pillars, and Implications for Human Action: Literature Review. Cogent Soc. Sci. 2019, 5. [CrossRef]

22. Shaaban, M.; Scheffran, J. Selection of Sustainable Development Indicators for the Assessment of Electricity Production in Egypt. Sustain. Energy Technol. Assess. 2017, 22, 65-73. [CrossRef]

23. McGregor, D.; Simon, D.; Thompson, D. The Peri-Urban Interface: Approaches to Sustainable Natural and Human Resource Use; Earthscan: London, UK, 2012. [CrossRef]

24. Panda, S.; Chakraborty, M.; Misra, S.K. Assessment of Social Sustainable Development in Urban India by a Composite Index. Int. J. Sustain. Built Environ. 2016, 5, 435-450. [CrossRef]

25. Moreno Pires, S.; Fidélis, T.; Ramos, T.B. Measuring and Comparing Local Sustainable Development through Common Indicators: Constraints and Achievements in Practice. Cities 2014, 39, 1-9. [CrossRef]

26. Kötter, T.; Friesecke, F. Developing Urban Indicators for Managing Mega Cities; The World's Population: Washington, DC, USA, 2009; pp. 1-17.

27. Hiremath, R.B.; Balachandra, P.; Kumar, B.; Bansode, S.S.; Murali, J. Indicator-Based Urban Sustainability-A Review. In Energy for Sustainable Development; Elsevier: Amsterdam, The Netherlands, 2013; pp. 555-563. [CrossRef]

28. Mori, K.; Christodoulou, A. Review of Sustainability Indices and Indicators: Towards a New City Sustainability Index (CSI). Environ. Impact Assess. Rev. 2012, 32, 94-106. [CrossRef]

29. Shen, L.Y.; Jorge Ochoa, J.; Shah, M.N.; Zhang, X. The Application of Urban Sustainability Indicators-A Comparison between Various Practices. Habitat Int. 2011, 35, 17-29. [CrossRef]

30. Verma, P.; Raghubanshi, A.S. Urban Sustainability Indicators: Challenges and Opportunities. Ecol. Indic. 2018, 93, 282-291. [CrossRef]

31. Klopp, J.M.; Petretta, D.L. The Urban Sustainable Development Goal: Indicators, Complexity and the Politics of Measuring Cities. Cities 2017, 63, 92-97. [CrossRef]

32. Arha, A.; Audichya, R.; Pant, D.C. Challenges in the Urban and Peri-Urban Transition Zones and Strategies for Sustainable Cities: Experiences from Selected Cities. In The Security of Water, Food, Energy and Liveability of Cities; Springer: Dordrecht, The Netherlands, 2014; pp. 71-85. [CrossRef]

33. Beynon, M.J.; Crawley, A.; Munday, M. Measuring and Understanding the Differences between Urban and Rural Areas. Environ. Plan. B Plan. Des. 2016, 43, 1136-1154. [CrossRef]

34. Karg, H.; Hologa, R.; Schlesinger, J.; Drescher, A.; Kranjac-Berisavljevic, G.; Glaser, R. Classifying and Mapping Periurban Areas of Rapidly Growing Medium-Sized Sub-Saharan African Cities: A Multi-Method Approach Applied to Tamale, Ghana. Land 2019, 8, 40. [CrossRef]

35. Varkey, A.M.; Manasi, S. A Review of Peri-Urban Definitions, Land Use Changes and Challenges to Development. Urban India 2019, 39, 96-111.

36. Bryant, C.R.; Russwurm, L.H.; McLellan, A.G. The City's Countryside: Land and Its Management in the Rural-Urban Fringe; Longman: London, UK, 1982.

37. Woltjer, J. A Global Review on Peri-Urban Development and Planning. J. Reg. City Plan. 2014, 25, 1-16. [CrossRef]

38. Chirisa, I.; Mazhindu, E.; Bandauko, E. Peri-Urban Developments and Processes in Africa with Special Reference to Zimbabwe; Springer: Berlin/Heidelberg, Germany, 2016. [CrossRef]

39. Geneletti, D.; La Rosa, D.; Spyra, M.; Cortinovis, C. A Review of Approaches and Challenges for Sustainable Planning in Urban Peripheries. Landsc. Urban Plan. 2017, 165, 231-243. [CrossRef]

40. Ravetz, J.; Fertner, C.; Nielsen, T.S. The Dynamics of Peri-Urbanization. In Peri-Urban Futures: Scenarios and Models for Land Use Change in Europe; Springer: Berlin/Heidelberg, Germany, 2013; pp. 13-44. [CrossRef]

41. Mpofu, G.; Darkoh, M.K.; Gwebu, T. Peri-Urbanization Landuse Dynamics: An Analysis of Evolving Patterns and Their Impacts on Gabane Village, Botswana. GeoJournal 2017, 1-17. [CrossRef]

42. MHUUC. Housing and Sustainable Urban Development in Arab Republic of Egypt National Report, 2016. [CrossRef] 
43. Ministry of Housing-Utilities and Urban Communities. Greater Cairo Urban Development Strategy; Part I: Future Vision and Strategic Directions; Ministry of Housing-Utilities and Urban Communities: Cairo, Egypt, 2012.

44. JICA. The Strategic Urban Development Master Plan (SDMP) Study for Sustainable Development of the Greater Cairo Region; JICA: Tokyo, Japan, 2008; Volume 1.

45. The World Bank. Towards an Urban Sector Strategy (Vol. 2); The World Bank: Washington, DC, USA, 2008.

46. Sims, D. Understanding Cairo; The American University in Cairo Press: Cairo, Egypt, 2011. [CrossRef]

47. Salem, M. Peri-Urban Dynamics and Land-Use Planning for the Greater Cairo Region in Egypt. In WIT Transactions on The Built Environment; WIT Press: Waterford, Ireland, 2015; Volume 168, pp. 109-119. [CrossRef]

48. Salem, M.; Tsurusaki, N.; Divigalpitiya, P.; Salem, M.; Tsurusaki, N.; Divigalpitiya, P. Analyzing the Driving Factors Causing Urban Expansion in the Peri-Urban Areas Using Logistic Regression: A Case Study of the Greater Cairo Region. Infrastructures 2019, 4, 4. [CrossRef]

49. Salem, M.; Tsurusaki, N.; Divigalpitiya, P.; Osman, T. Driving Factors of Urban Expansion in Peri-Urban Areas of Greater Cairo Region. In Proceedings of the 23rd International Conference on Urban Planning, Regional Development and Information, Vienna, Austria, 4-6 April 2018; pp. 191-196.

50. Jeníček, V. Sustainable Development-Indicators. Agric. Econ. (Czech Republic) 2013, 59, 74-80. [CrossRef]

51. Khalid, A.M.; Sharma, S.; Dubey, A.K. Developing an Indicator Set for Measuring Sustainable Development in India. Nat. Resour. Forum 2018, 42, 185-200. [CrossRef]

52. Adinyira, E.; Oteng-seifah, S.; Adjei-kumi, T. A Review of Urban Sustainability Assessment Methodologies. Int. Conf. Whole Life Urban Sustain. Assess. 2007, 8. [CrossRef]

53. UN. Technical Report by the Bureau of the United Nations Statistical Commission (UNSC) on the Process of the Development of an Indicator Framework for the Goals and Targets of the Post-2015 Development Agenda-Working Draft; UN: New York, NY, USA, 2015.

54. Kondyli, J. Measurement and Evaluation of Sustainable Development. A Composite Indicator for the Islands of the North Aegean Region, Greece. Environ. Impact Assess. Rev. 2010, 30, 347-356. [CrossRef]

55. Carraro, C.; Cruciani, C.; Giove, S.; Lanzi, E. Aggregation and Projection of Sustainability Indicators: A New Approach. Methodology 2009, 1-11.

56. Brugmann, J. Is There a Method in Our Measurement? The Use of Indicators in Local Sustainable Development Planning. Local Environ. 1997, 2, 59-72. [CrossRef]

57. Lu, Y.; Geng, Y.; Liu, Z.; Cote, R.; Yu, X. Measuring Sustainability at the Community Level: An Overview of China's Indicator System on National Demonstration Sustainable Communities. J. Clean. Prod. 2017, 143, 326-335. [CrossRef]

58. Huang, L.; Wu, J.; Yan, L. Defining and Measuring Urban Sustainability: A Review of Indicators. Landsc. Ecol. 2015, 30, 1175-1193. [CrossRef]

59. Li, F.; Liu, X.; Hu, D.; Wang, R.; Yang, W.; Li, D.; Zhao, D. Measurement Indicators and an Evaluation Approach for Assessing Urban Sustainable Development: A Case Study for China's Jining City. Landsc. Urban Plan. 2009, 90, 134-142. [CrossRef]

60. Nallathiga, R.; Taneja, S.; Gupta, A.; Gangal, B. Sustainability of Urban Fringe Development and Management in NCT-Delhi: A Case Study. In Exploring Urban Change in South Asia; Springer: Berlin/Heidelberg, Germany, 2018; pp. 109-133. [CrossRef]

61. OECD Health Division. Health at a Glance: Europe 2018; OECD Health Division: Paris, France, 2018. [CrossRef]

62. Singerman, D.; Amar, P. Cairo Cosmoplitan Politics, Culture, and Urban Space in the New Globalized Middle East; American University: Cairo, Egypt, 2006. [CrossRef]

63. Yarmohammadian, M.H.; Rezaei, F.; Haghshenas, A.; Tavakoli, N. Overcrowding in Emergency Departments: A Review of Strategies to Decrease Future Challenges. J. Res. Med. Sci. 2017, 22. Isfahan University of Medical Sciences(IUMS) 2017. [CrossRef]

64. TADAMUN. Planning [In]Justice: Spatial Analysis for Urban Cairo; TADAMUN: Cairo, Egypt, 2016.

65. Salem, M.; Tsurusaki, N.; Divigalpitiya, P. Fractal Dimension as A Descriptor of Expansion of Peri-Urban Areas in Greater Cairo Region. In 3nd International Exchange and Innovation Conference on Engineering $\mathcal{E}$ Sciences; Graduate School of Engineering Sciences, Kyushu University: Fukouka, Japan, 2017; Volume 3, pp. 115-117.

66. Radwan, T.M.; Blackburn, G.A.; Whyatt, J.D.; Atkinson, P.M. Dramatic Loss of Agricultural Land Due to Urban Expansion Threatens Food Security in the Nile Delta, Egypt. Remote Sens. 2019, 11, 332. [CrossRef] 
67. Osman, T.; Shaw, D.; Kenawy, E. An Integrated Land Use Change Model to Simulate and Predict the Future of Greater Cairo Metropolitan Region. J. Land Use Sci. 2018, 13, 565-584. [CrossRef]

68. Baseera. Localizing the Targets of the Sustainable Development Goals on Governorate Level Study; Baseera: Cairo, Egypt, 2018. 